\title{
Development Research of psychology education under the background of humanism
}

\author{
Yanmei ZHANG \\ Weifang University of Science and Technology \\ Shouguang,Shandong, 262700 China
}

\begin{abstract}
With the development of modern education, and the progress of social civilization, cognitive level of teachers and students is also rising, while continuing to update the modern teaching equipment, methods of psychology education also have changed to a large extent compare with the past. In this paper, to improve teaching standards of teachers, curriculum content and teaching objectives optimization is a starting point to explain educational psychology. In theory and practice to improve the teaching of psychology and to optimize students' cognitive ability and attitude for learning, focus on efficiency and innovative multimedia teaching, so that teachers can scientifically recognize the great impact of the use of educational theories and new methods on optimizing educational psychology, and thus improve teaching and actively conduct a study. It has far-reaching significance for developing students' innovative ability and improving their competitiveness of social existence.
\end{abstract}

Keywords- Humanism, psychology education, development

\section{INTRODUCTION}

Humanistic Psychology opposes environmental determinism of behaviorist psychology and biological reductionism of psychoanalysis, psychology, and it is called the "third force" of Psychology. Its main representatives are Maslow, Rogers, Rollo May and Burgundy $\bullet$ Tal and so on. The basic point is: adhere to the human experience as a starting point, emphasize integrity, uniqueness and autonomy; adhere to the body's potential, based on its optimistic outlook for people and emphasize the possibility of future development; adhere to human values and personality development as the focus, emphasis on self-realization, selfselection and healthy personality as the pursuit of life goals; adhere to a wide range of social problems for the content, emphasizing the implementation of education reforms, psychotherapy, crime prevention and social transformation. Education reform theory of humanistic psychology and education reform experiment based on humanistic psychology, have a great impact on the reform of the existing education.

\section{AN ORIGIN OF HUMANISTIC PSYCHOLOGY}

Humanistic Psychology produced in the United States, and quickly be spread by the social conditions. United States in World War II, made a fortune of the war. After the war, economy developed rapidly, people's living standards greatly improved. But increasingly fierce competition of capitalism led to the emergence of unemployment, juvenile delinquency, loss of moral values and other social issues. Especially since the 1960s, American society appeared counter-culture movement, the majority of young people on social discontent, fight for the civil rights movement, opposition to the war in Vietnam, people called for education and university reform protest against environmental pollution and so on. People were living in the international threat of arms race and nuclear war, and had a great psychological pressure, thoughts were very confusing, people created enormous wealth, in turn, it dominated people, enslaved people, people fell into a passive, wander, the plight of anxiety, the spirit with extreme emptiness. Under these conditions, humanistic psychology found the space of their own existence and development. Humanistic psychologists believe that, the fundamental reason of many disturbing factors is that people were lack of scientific understanding of the intrinsic value. In these social and historical conditions, humanistic psychologists proposed to care about human dignity and values and quickly accepted by the community, and have promoted the spread and development of humanistic ideas.

\section{EdUCATIONAL CONCEPT OF HUMANISTIC PSYCHOLOGY}

Humanistic Psychology produced in the late 1950s early 1960 s, with the development of humanistic psychology to become a third trend, humanistic psychologist Maslow and Rogers promoted penetration and application of Humanistic Psychology in Education, and promote the formation of Humanistic Education. The educational philosophy of Humanistic Psychology major emphasizes the following points: First, the educational goal is to promote the harmonious development of students' overall personality. The humanistic concept of education emphasizes that through education enable students have freedom inherent characteristics and can adapt to change, know how to learn. Second, the process of education is to promote students' selfrealization. Educational concept of humanism believes that human nature is positive, self-realization. Educational process is student-centered, stimulates students' enthusiasm, prompts students to self-directed, freedom to learn, so that inherent potential of students can be developed and mined under certain conditions, in order to achieve themselves. Third, the basic principle of education is humanism. Humanism Education emphasizes human worth and dignity, pays attention to students' emotions, needs and desires, and also individual differences, self-concept and personal choice, 
respecting and understanding students, advocating the creation of a harmonious atmosphere of harmony, love and understanding, emphasizing unconditional positive attention to student growth. Fourth, education pattern emphasizes learning by doing. Educational concept of humanism believes that learning from doing allows students to experience real problems, face personally meaningful or relevant issues; learning to solve problems in personal experience is one meaningful way to promote learning.

\section{PHILOSOPHICAL FOUNDATION OF HUMANISTIC PSYCHOLOGY}

\section{A. Existentialism}

The founders of Humanistic Psychology Maslow, Rogers put existentialism as an important source of inspiration for humanistic psychology and existentialist philosophy is regarded as the basis of its entire theory. From the research proposition, the existentialism put an emphasis on human existence, the value of human existence, advocated peopleoriented, lifted human personality, it provides science-based and theoretical premise for humanistic psychology.

About human nature, Before humanistic psychology, psychology has forgotten its most fundamental point, that is human, the person who is a finished core. Existentialism give a very important ideological inspiration for humanist psychologist: understanding must use irrational inner experience, inner intuitive. Thus the humanistic psychologists have found an important breakthrough: Exploring inside, beginning from the experience.

It emphasized the unique selectivity. Sartre said: the essence of human can be freedom to choose and create out and show their significance and value in the process. In the eyes of existentialism, freedom based on personal choice, they focus on human survival and development; inevitably emphasize human autonomy choice and creativity, due to the influence of existentialism, humanistic psychology is starting from the beginning of human existence, to concern people, ordinary people, and advocate individual attention to their existence. Humanistic Psychology is compatible with science and reason, advocate the research attitude of compromised fusion and inclusive, and existentialism emphasizes irrationality while completely rejects rationality.

\section{B. Phenomenology}

Phenomenology through the study of "exist within pure consciousness ", thereby revealing the essence of human life world, from a purely subjective way to achieve" interactive subjectivity "of the world, one of the most important features is that it emphasizes the study of subjective experience, emphasizes whole or integrated approach and man is the dynamic interpreter of his own subjective world and the objective world, so phenomenology, including the reduction analysis, intention analysis and analysis of returning the living world, directly or indirectly have a significant impact on humanistic psychology.

\section{SELF-DEVELOPMENT PSYCHO-EDUCATION}

Learning theory of humanistic psychology emphasizes the dignity and worth of the human, the basic learning principles must respect students, pay attention to their wishes, feelings and ideas, and considers that learning can play individual potential, develop human personality and realize the values of human. Humanistic Psychology presents instructional design of open education, the main features are: students lead their own learning; using diagnostic assessment results; do not use fixed textbook teaching; using individualized teaching activities; hybrid teaching mode; using open classroom; collaborative teaching based on teacher collaboration. Under the guidance of this theory, the United States from family education to school education, social education from school education have attached great importance to the opportunities to develop personality for students. Hierarchical teachings, guidance, team teaching, team teaching in American schools, are forms of individualized teaching. American students have the activities such as housework, social practice, science and technology activities, simulation creation and other activities to display their individual talents.

China's education policy clearly stipulates that people should cultivate the comprehensive development of moral, intellectual, physical. This approach proposed high-level requirements to human development. However, from the current level of China's overall social development, to fully implement this policy is still quite difficult. Moreover, with a unified plan, consistent content to require all students, in fact, it is difficult to make vastly different students get comprehensive education. Personality development is included in the overall development and requested comprehensive development on the basis of personality development, not only in line with the law of education, but also has the conditions to achieve. Under the guidance of education reform theory of humanistic psychology school, the United States attaches great importance to the development of talents. American educators believe that in the human and social development, people are in the dominant position, human development is the final decisive power of social development, therefore, to seize the human development, is to seize the power of development of all things in the society., starting from this understanding, the United States at all costs will develop people's potential, always put human development as the primary goal of education. Similarly, China also attaches importance to human development, but compared with the United States the degree of attention and efforts we actually made it are very far. If China wants to have strategic initiative in international competition in the future, we should so like American education, to improve the quality of people, human potential, realize the value of people, as the highest goal of education, and stick to it. 


\section{PEOPLE-ORIENTED: THE INTEGRATION OF THE} CONCEPT OF CONTEMPORARY PSYCHOLOGICAL EDUCATION

In the modern social conditions, whether it is from the perspective of social development or from the perspective of personal development, people-oriented issues must be presented. Here, we promote education should be peopleoriented, to replace the humanistic education is based on this consideration: the subject of humanistic education is peopleoriented, but it's the thought excessive emphasis on the individual self, and the relative neglect of social and collective action. Since the 1980 s, criticism and reflection of humanistic education from Western society is the reintegration of corrective and ideas. We promote peoplecentered concept of education, is to learn the essence of the humanist educational thought, to use it to guide our educational practice, and has profound theoretical and practical significance.

\section{A. To shape healthy personality, achieve educational ideals of humanism}

Education is to train people. Every society hope to train the personnel needed by society through education, and therefore, all education community have established the image of the ideal man. It can be said, "There is no certain ideal of educated people, it cannot engage in education." Through historical review of humanism and its educational ideology, we noted that the cultural side of the ancient Greek tradition, whether it is the ancient Chinese Confucianism or Western scholars, their ideals of education have one thing in common, that is, people believe nature can be modeled, perfect personality can be stood out in the ideals of humanism in education.

\section{B. To emphasize the role of teachers, and form a people- centered view of teacher}

Educational Thought of humanistic psychology emphasizes self-selection, self-evaluation in the learning process, lays emphasis on individual perception and inner experience, and pays attention to student-centered teaching, and the importance of teaching to personal growth. But the humanistic psychologists and educators has never denied the importance for students to study hard. Teachers do not care how much knowledge the students get, but make the effort to train students to respect knowledge, have a strong desire to learn and form the right attitude towards learning, and learn according to their actual situation to arrange learning to become masters of knowledge.

\section{CONCLUSION}

After low-level human needs are met, hierarchy of needs does not naturally transit to senior needs, in Maslow's view, a high level need is a kind of potential energy, with "instinctlike" features, and compared to strength of animal instinct, it is more vulnerable to be depressed, controlled, changed, or even disappears. As Maslow said: "I am baffled why the rich makes some people develop, leave the others staying on the level of 'materialism', maybe we need add one more piece on the definition of self-actualization, namely that he is not only physical health, basic needs are met, but also faithful to some values he is fighting and groping. " This determines the educators can meet the reasonable low-level needs of students while effectively use the method of spiritual care to wake up and inspire students' hidden spiritual needs in the depths of the soul, in order to improve students' spiritual realm, to play incentives of high-level needs to guide the students' action, so that students can establish the correct values, form the intrinsic motivation of self-motivation, selfshaping and promote the development of individual students to achieve self-realization.

\section{REFERENCES}

[1] Zhuji Yun. Discuss sports psychology education college physical education integration $[\mathrm{J}]$. Gansu Lianhe University (Natural Science), 2008,02:96-98.

[2] Liu Jie. Revelation humanistic psychology graduate students ideological and political education of the [D]. Southwest Petroleum University, 2012.

[3] Li Fusheng. Humanistic Psychology Educational Thought and Ideological and Political Education [D]. Zhengzhou University, 2007.

[4] Xie Jun. role of education in school history resource based on humanistic psychology research. [J]. Office business,2012,09:34 -35 +38 .

[5] Wu Xiaofei. from the perspective of human psychology, humanistic psychology education for young people to explore learning $[\mathrm{J}]$. Anhui Literature (second half), 2010,07:199.

[6] Fang Qiuxiang. based educational research methodology of humanistic psychology [J]. Leshan Teachers College,2005,10:120123.

[7] Yang Yanchang. study based on effective teaching strategies of humanistic psychology[D]. Sichuan Normal University, 2010 